\title{
Definitive radiotherapy or chemoradiotherapy results and side effects in elderly bladder cancer patients
}

\section{Yaş\| mesane kanseri hastalarında, definitif radyoterapi veya kemoradyoterapi sonuçları ve yan etkileri}

\author{
Birsen Yücel, Eda Erdiș
}

Medical School of Sivas Cumhuriyet University, Department of Radiation Oncology, Sivas, Turke

Corresponding author: Birsen Yücel, MD, Medical School of Sivas Cumhuriyet University, Department of Radiation Oncology, Sivas, Turkey

E-mail: yucelbirsen@yahoo.com

Received/Accepted: November 06, 2019 /November 28, 2019

Conflict of interest: There is not a conflict of interest.

\section{SUMMARY}

Objective: Bladder cancer is most commonly observed in elderly patients. In these patients, it is not always possible to give the necessary treatment for the disease. In this study, definitive radiotherapy (RT) or chemoradiotherapy (CRT) results and side effects, as well as prognostic factors, were investigated in elderly bladder cancer patients.

Method: The results of 36 elderly patients who received definitive RT or CRT for bladder cancer between the years 2010-2018 in Sivas Oncology Center of Cumhuriyet University Medical Faculty were analyzed retrospectively.

Results: The median age of the patients was 75 (range, 65-84). Sixteen patients (44\%) underwent RT without chemotherapy and 20 patients (56\%) received CRT. Complete response was detected in $19(53 \%)$ patients. The median survival was 18 months (range 3-102 months) and the overall 2 -year survival rate was $37 \%$. Treatment response $(\mathrm{p}<.001)$ and performance status of the patients $(\mathrm{p}=.001)$ were found to be statistically significant prognostic factors in patients' survival. However, sex, comorbidity, Charlson Comorbidity index, risk groups, treatment modality (RT vs. CRT), presence of in situ, grade, status of tumor foci (unifocal vs. multifocal), degree of tumor resection in transurethral resection of the bladder (TUR-B, complete vs. incomplete resection), chemotherapy after CRT, concurrent chemotherapy regimen (ciplatin vs.gemcitabine), RT dose ( $<60 \mathrm{~Gy}$ vs. $\geq 60 \mathrm{~Gy}$ ), and the device used in RT (linac vs. TomoTherapy) were not statistically significant.

Conclusions: Good performance and completed response to treatment in elderly bladder cancer patients positively affects survival.

Keywords: Bladder cancer, elderly patients, radiotherapy, chemoradiotherapy

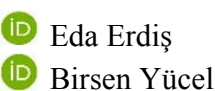

ORCID IDs of the authors: E.E. 0000-0003-3003-8643 B.Y. 0000-0002-2083-6866 
Bulgular: Hastaların ortanca yaşı 75 (65-84) idi. On altı hastaya (\% 44) kemoterapi olmadan RT uygulandı ve 20 hastaya (\%56) KRT uygulandı. Tam cevap 19 (\%53) hastada tespit edildi. Ortanca sağkalım 18 aydı (aralık: 3-102 ay) ve toplam 2 yıllık genel sağkalım oranı \%37 idi. Tedavi yanıtı $(\mathrm{p}<.001)$ ve hastaların performans durumları $(\mathrm{p}=.001)$ hastaların sağkalımında istatistiksel olarak anlamlı prognostik faktörler olarak bulundu. Bununla birlikte, cinsiyet, komorbidite, Charlson Komorbidite indeksi, risk grupları, tedavi yöntemi (RT ve KRT), in situ varlığı, derecesi, tümör odaklarının durumu (unifokal ve multifokal), mesanenin transüretral rezeksiyonunda tümör rezeksiyonu derecesi (TURB, tam ve eksik rezeksiyon), KRT sonrası kemoterapi, eşzamanlı kemoterapi rejimi (siplatin vs. gemsitabin), RT dozu ( $<60$ Gy vs. $\geq 60$ Gy) ve RT'de kullanılan cihaz (linak vs. TomoTherapy) istatistiksel olarak anlamlı değildi.

Sonuç: Yaşlı mesane kanseri hastalarında iyi performans ve tedaviye verilen cevap sağkalımı olumlu yönde etkilemektedir.

Anahtar sözcükler: Mesane Kanseri, yaşlı hastalar, radyoterapi, kemoradyoterapi

\section{INTRODUCTION}

Bladder cancer is the sixth most common cancer of all body cancers. It ranks fourth among males and eleventh among females ${ }^{1}$. In addition, bladder cancer is the second most common urologic malignancy ${ }^{2}$. Seventy percent of bladder cancer cases are observed as non-muscle invasive and $30 \%$ are observed as muscle invasive ${ }^{3}$. However, $50-70 \%$ of non-muscle-invasive tumors are recurrent despite transurethral and intravesical treatments ${ }^{4,5}$.

Radical cystectomy with neoadjuvant chemotherapy is the standard recommended treatment for tumors with muscle invasion. In some bladder cancer patients, bladder-sparing treatment may be an alternative to radical cystectomy. In particular, bladder-sparing treatment may be considered in patients with unifocal T2-3 tumors, those with adequate renal function for cisplatin administration, and those without urethral obstruction and in situ disease ${ }^{6-8}$. In addition, chemoradiotherapy (CRT) may be a treatment option in medically inoperable patients who do not prefer radical cystectomy or in patients with comorbid diseases. In bladdersparing treatment, maximal transurethral resection of the bladder (TUR-B) is performed first. After complete resection of the bladder, the patient is treated with CRT.

As a result of the growth of the global elderly population, there is an increase in cancer cases and in patients requiring continuous medical care. This is especially true in patients with cancers that have a long latency period, such as urothelial bladder carcinoma, in which the peak incidence is at an advanced age ${ }^{9}$. Indeed, the median age of diagnosis of patients with bladder cancer is 73 , and more than two-thirds of cases occur in people 65 years and older 1. Amongst the elderly population, patients are often affected by multiple comorbidities, such as diabetes, hypertension and heart disease that limit tolerance to curative surgical treatment and other treatments. Often, due to the low physiological reserves of older people, physicians will have difficulty in deciding whether the preferred treatment would be radical cystectomy. Therefore, alternative therapies for radical cystectomy may come to the fore in these patients, especially those with muscle-invasive tumors. Some elderly patients who would be candidates for CRT are considered not to be good candidates for this treatment due to medical problems.

In this study, treatment results and side effects of elderly patients treated with definitive radiotherapy (RT) or CRT for bladder cancer were investigated. In addition, prognostic factors affecting the survival of elderly patients were investigated.

\section{MATERIAL AND METHODS}

The results of 36 elderly patients who received definitive RT or CRT for bladder cancer between the years 2010-2018 in Sivas Oncology Center of Cumhuriyet University Medical Faculty were analyzed retrospectively. The study was approved by the Ethics Committee of Sivas Cumhuriyet University. Patients aged 65 years and over with bladder cancer, but without distant metastases, who underwent definitive RT or CRT and who did not accept radical cystectomy, or were not medical inoperable for cystectomy, were included in the study.

The staging of the disease was performed according to AJCC 8th TNM staging (2016) ${ }^{10,11}$. The performance status of the patients was evaluated according to The Eastern Cooperative Oncology Group (ECOG) performance criteria ${ }^{12}$.

For the patients, two risk groups have been described according to $\mathrm{T}$ stage, tumor size, tumor number, presence of in situ and presence of hydronephrosis. The first is the standard risk group: T1-3 tumor, tumor less than $5 \mathrm{~cm}$, unifocal, in situ-free, and hydronephrosis-free. The second group is the high-risk group: T4 tumor, tumor larger than $5 \mathrm{~cm}$, multifocal, 
presence of in situ, and presence of hydronephrosis.

Radiotherapy was performed using linear accelerators (The Varian DHX device, $\mathrm{N}=28$, $78 \%)$ and TomoTherapy $(\mathrm{N}=8,22 \%)$ with standard fractionation. Eclipse (ver. 8.6; Varian Medical Systems, Inc. Palo Alto, CA, USA) was used as the three-dimensional conformal radiotherapy (3DRT) planning software program. VoLO planning system (Tomo HD VoLO planning system, Accuray Inc. Madison, WI, USA) was used as the intensity modulated radiotherapy.

First, the patients were given a total of 40-45 Gy RT from 1.8 Gy per day from the pelvic area (obturator, internal and external iliac lymph nodes, whole bladder), and a boost dose was planned considering the normal organ dose limitation. Radiotherapy-induced side effects were assessed according to The Radiation Therapy Oncology Group (RTOG) Acute Radiation Morbidity Scoring Criteria ${ }^{13}$. Weekly cisplatin $\left(35 \mathrm{mg} / \mathrm{m}^{2}\right)$ or gemcitabine $\left(400 \mathrm{mg} / \mathrm{m}^{2}\right)$ was used as the concomitant chemotherapy agent.

\section{Treatments}

TUR-B was performed in 33 (92\%) patients. Only $10(30 \%)$ patients underwent complete resection of TUR. Four (11\%) patients received intravesical therapy. Sixteen patients (44\%) underwent RT without chemotherapy and only 20 patients $(56 \%)$ were suitable to receive CRT. The median RT dose was 52.2 Gy (16.2-64.8 Gy). Simultaneous chemotherapy regimens were carried out; 9 (45\%) patients received weekly gemcitabine and 11 (55\%) patients received weekly cisplatin. After CRT, 9 (25\%) patients received maintenance chemotherapy. None of the patients underwent cystectomy after CRT.

\section{Statistics}

SPSS version 22 was used for statistical analysis. Descriptive tests (frequencies, descriptive, standard deviation) were used to describe the characteristics of the patients and the Kaplan Meiere test was used for survival analysis. Pvalues $p<0.050$ were considered as significant.

\section{RESULTS}

When the data of 36 patients with bladder cancer were examined, it was found that $31(86 \%)$ of the patients were male and $5(14 \%)$ were female. The median age of the patients was 75 (range, 65-84). Twenty-seven patients (75\%) had comorbidity. According to Charlson Comorbidity Scoring: there were $12(34 \%)$ patients with 5 points; 13 (36\%) patients with 6 points; $8(22 \%)$ patients with 7 points; and $3(8 \%)$ patients with 8 points ${ }^{14}$. All patients had histopathology of urothelial carcinoma and none had hydronephrosis. The characteristics of the patients are shown in Table 1. Treatment-related adverse events, acute and late side effects are shown in Table 2.

Complete response was detected in 19 (53\%) patients. Complete response was observed in 8 $(42 \%)$ patients who received RT without chemotherapy and in $11(58 \%)$ patients who received CRT $(\mathrm{p}=.515)$. Local recurrence occurred in $8(22 \%)$ patients and distant metastasis developed in $7(19 \%)$ patients. The median survival was 18 months (range 3-102 months) and the overall 2-year survival rate was $37 \%$. 
Table 1: The patients characteristics.

\begin{tabular}{|c|c|c|}
\hline & No of patients & $\%$ \\
\hline \multicolumn{3}{|l|}{ Sex } \\
\hline Male & 31 & 86 \\
\hline Female & 5 & 14 \\
\hline Comorbidity & 27 & 75 \\
\hline Hypertension & 16 & 44 \\
\hline Coronary artery disease & 9 & 25 \\
\hline Diabetes mellitus & 8 & 22 \\
\hline Renal disease & 3 & 8 \\
\hline \multicolumn{3}{|l|}{ Charlson Comorbidity index } \\
\hline 5 point & 12 & 34 \\
\hline 6 point & 13 & 36 \\
\hline 7 point & 8 & 22 \\
\hline 8 point & 3 & 8 \\
\hline \multicolumn{3}{|l|}{ Stage of initial daignosis } \\
\hline Superficial stage (Ta, T1) & 9 & 25 \\
\hline $\mathrm{T} 2$ and high & 27 & 75 \\
\hline \multicolumn{3}{|l|}{ Stage } \\
\hline Stage I & 3 & 8 \\
\hline Stage II & 25 & 70 \\
\hline Stage III & 8 & 22 \\
\hline \multicolumn{3}{|l|}{ Grade } \\
\hline Grade I & 2 & 6 \\
\hline Grade II & 2 & 6 \\
\hline Grade III & 32 & 88 \\
\hline \multicolumn{3}{|l|}{ İn situ } \\
\hline No & 28 & 78 \\
\hline Yes & 8 & 22 \\
\hline \multicolumn{3}{|l|}{ The number of tumor } \\
\hline Unifocal & 19 & 57 \\
\hline Multifocal & 17 & 43 \\
\hline \multicolumn{3}{|l|}{ Risk } \\
\hline Standard risk & 17 & 47 \\
\hline High risk & 19 & 53 \\
\hline
\end{tabular}


Table 2: Adverse events and toxicities.

\begin{tabular}{|c|c|c|}
\hline & No of patients & $\%$ \\
\hline The planned treatment incompleted & 5 & 14 \\
\hline Interruption of treatment & 7 & 19 \\
\hline Deterioration of performance status & 13 & 36 \\
\hline \multicolumn{3}{|c|}{ Acute toxicities } \\
\hline \multicolumn{3}{|l|}{ Lower gastrointestinal } \\
\hline Grade $1-2$ & 20 & 56 \\
\hline \multicolumn{3}{|l|}{ Genitourinary } \\
\hline Grade $1-2$ & 24 & 67 \\
\hline Grade $3-4$ & 2 & 6 \\
\hline \multicolumn{3}{|l|}{ White blood cell } \\
\hline Grade $1-2$ & 11 & 32 \\
\hline Grade $3-4$ & 2 & 6 \\
\hline \multicolumn{3}{|l|}{ Platelet } \\
\hline Grade $1-2$ & 2 & 6 \\
\hline Grade $3-4$ & 3 & 8 \\
\hline \multicolumn{3}{|l|}{ Neutrophil } \\
\hline Grade $1-2$ & 4 & 11 \\
\hline Grade 3-4 & 2 & 6 \\
\hline \multicolumn{3}{|l|}{ Hemoglobin } \\
\hline Grade $1-2$ & 14 & 39 \\
\hline \multicolumn{3}{|l|}{ Hematocrit } \\
\hline Grade $1-2$ & 6 & 17 \\
\hline \multicolumn{3}{|c|}{ Late toxicites } \\
\hline Lower Gastrointestinal $^{\dagger}$ & & \\
\hline Grade 3-4 & 1 & 3 \\
\hline
\end{tabular}

$\dagger$ Pathologically proven

Treatment response $(\mathrm{p}<.001)$ and performance status of the patients $(p=.001)$ were found to be statistically significant prognostic factors in patients' survival. The survival curves of statistically significant prognostic factors are presented in Figure 1. However, sex, comorbidity, Charlson Comorbidity index, risk groups, treatment modality (RT vs. CRT), presence of in situ, grade, status of tumor foci (unifocal vs. multifocal), degree of tumor resection in TUR (complete vs. incomplete resection), chemotherapy after CRT, concurrent chemotherapy regimen (ciplatin vs.gemcitabine), RT dose ( $<60$ Gy vs. $\geq 60$ Gy), and the device used in RT (linac vs. TomoTherapy) were not statistically significant. The prognostic factors in univariate analysis are shown in Table 3. 
Survival Functions

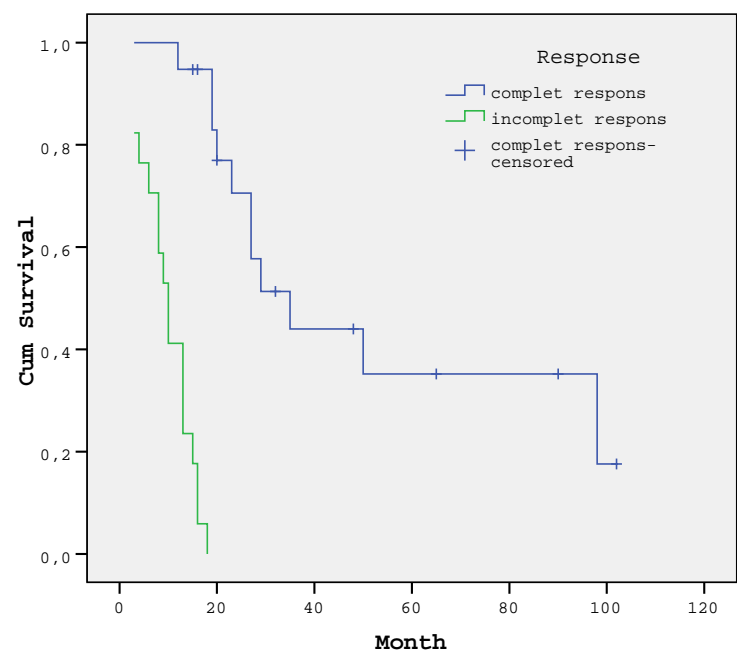

Survival Functions

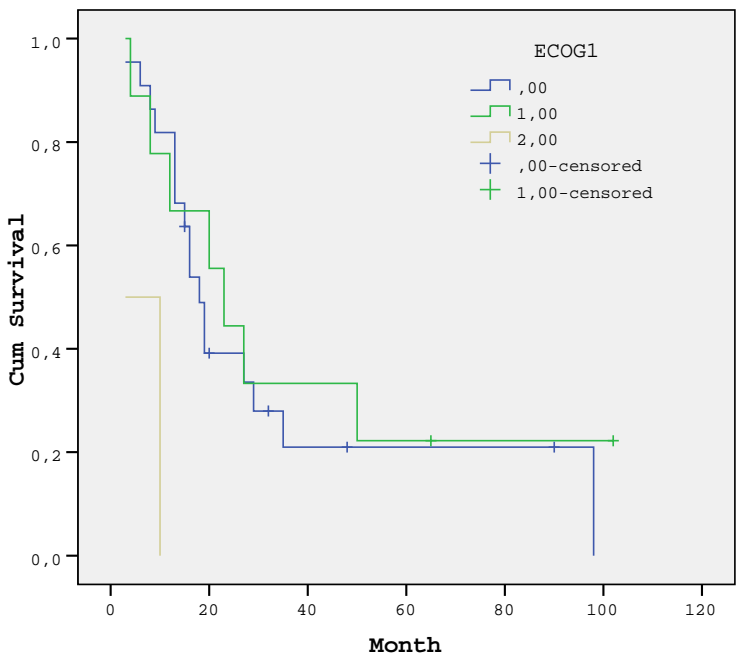

Figure 1: The survival curves according to treatment response and performance status (ECOG).

Table 3: The prognostic factors in univariate analysis.

\begin{tabular}{|l|c|c|c|c|}
\hline & $\begin{array}{c}\text { No of patients } \\
(\%)\end{array}$ & $\begin{array}{c}\text { The 2 years } \\
\text { overall survival }\end{array}$ & $\begin{array}{c}\text { The median } \\
\text { survival }\end{array}$ & P value \\
\hline $\mathrm{RT}^{\dagger} / \mathrm{CRT}^{\ddagger}$ response & $19(53)$ & 71 & 35 & $<0.001$ \\
Complet response & $17(47)$ & - & 10 & \\
Incomplet response & $22(61)$ & 34 & 18 & 0.001 \\
\hline ECOG & $9(23)$ & 33 & 23 & \\
ECOG 0 & $4(11)$ & - & 3 & \\
ECOG 1 & $16(44)$ & 31 & 15 & 0.350 \\
ECOG 2 and high & $20(56)$ & 35 & 19 & \\
\hline Treatment & 21 & 20 & 16 & 0.562 \\
RT & 15 & 37 & 19 & \\
CRT & $28(78)$ & 32 & 16 & 0.197 \\
\hline RT dose & $8(22)$ & 54 & NR & \\
$<60$ Gy & & & 18 & 0.751 \\
$\geq 60$ Gy & $17(47)$ & 37 & 16 & \\
\hline Radiotherapy devices & $19(53)$ & 29 & & \\
Lineer accerator & & & \\
TomoTherapy & & & & \\
\hline Risk & & & \\
Standard risk & & & \\
High risk &
\end{tabular}

"RT: Radiotherapy, ${ }^{\ddagger} \mathrm{CRT}$ : Chemoradiotherapy, ${ }^{\S} \mathrm{NR}$ : Not reached. 


\section{DISCUSSION}

Although radical cystectomy is the standard treatment for muscle-invasive bladder cancers and frequently recurrent superficial tumors, some of the patients do not want to lose their bladder. In some patients, especially elderly people with comorbid disease, their physiological reserves are not suitable for surgery. Therefore, alternative therapies for radical cystectomy are being investigated especially in selected patients. CRT may be an alternative treatment for these patients. RTOG The Radiation Therapy Oncology Group (RTOG) has been investigating treatments that protect the bladder since the $1980 \mathrm{~s}^{15-21}$. The group has undertaken a number of CRT studies with various chemotherapy agents. In these studies, 5-year overall survival rates were found to be $49.5-71.75 \%$ 16-21. Massachusetts General Hospital published the data of 475 bladder cancer patients treated with TUR-B + CRT (simultaneous cisplatin, 5FU, paclitaxel, gemcitabine, median RT dose 64 Gy) between 1986 and 2013. The Median follow-up was 7.21 years: complete response was $75 \%, 5$ and 10 -year overall survival were $57 \%$ and $39 \%, 5$ and 10 -year diseasespecific survival were $66 \%$ and $59 \%$, respectively. The patients in this study were selected for bladder-sparing therapies and survival rates of elderly patients were not indicated. However, advanced age at diagnosis has been reported to be a poor prognostic factor for overall survival ${ }^{22}$.

Wujanto et al. analyzed the survival of 45 bladder cancer patients treated between 2002 and 2017 with a median age of 77 (range 65-95). In this study, the median RT dose was 65 Gy (range 5069.8 Gy). CRT was administered to $21(47 \%)$ patients and RT was administered to $24(53 \%)$ patients. Forty-two patients $(93 \%)$ completed the planned treatment. The 2-year overall survival was $64 \%$. In this study, the performance of patients was identified as a prognostic factor affecting survival ${ }^{23}$. Forty-four percent of our patients did not receive concomitant chemotherapy and $14 \%$ did not complete the planned treatment. In addition, 36\% of patients' performance status deteriorated during treatment.

Lee et al. investigated CRT in elderly bladder cancer patients. Nineteen patients with a median age of 79.5 were included in the study. Median RT dose was 58.6 Gy (range 54-62.8). Chemotherapy agent gemcitabine or carboplatin was used and grade 3-4 neutropenia was observed in $53 \%$ of the patients as a major adverse event. In the study, 2-year overall survival was reported as $74 \%$ and 3 -year overall survival as $60 \%{ }^{24}$.
In 2014, Turgeon et al. investigated hypofractionated RT in 24 bladder cancer patients age 70 years and over (median 79 years). A total of 40 Gy RT was administered to the pelvic area from 2 Gy daily to the patient and 2.5 Gy to 2.5 Gy daily to the bladder. All patients were taken to RT by Intensity Modulated Radiotherapy (IMRT) technique. Simultaneously, cisplatin or gemcitabine or gemcitabine + everolimus was administered to RT. Complete response was achieved in $83 \%$ of the patients. The 3-year overall survival was $61 \%$. Acute grade 3 gastrointestinal or genitourinary toxicities occurred in only $4 \%$ of patients and acute grade 3-4 hematologic toxicity occurred in $17 \%$. ${ }^{25}$. Compared with the study of Turgeon et al., the treatment response of our study was found to be quite low $(53 \%)$. Furthermore, the addition of chemotherapy to radiotherapy did not alter this outcome in our study. Complete response was observed in $42 \%$ patients who received RT without chemotherapy and in $58 \%$ patients who received CRT $(\mathrm{p}=.515)$.

Hsieh et al. evaluated the results of 19 elderly patients with bladder cancer irradiated with IMRT $(\mathrm{N}=9)$ and Helical Tomo Therapy $(\mathrm{N}=10)$. The median age of the patients was 80 years (range 65-90 years). Median 64.8 Gy RT was administered to patients whether or not they received concurrent chemotherapy. The median survival of all patients was 21 months (5-26 months), The actuarial 2 years overall survival was $26.3 \%$ in IMRT and $37.5 \%$ in Helical Tomo Therapy, respectively ${ }^{26}$. In contrast to the above study, we did not statistically find any difference in survival in terms of 3DRT and TomoTherapy irradiation in our study. The 2-year overall survival was $32 \%$ and $54 \%$ in 3 DRT and Tomo Therapy, respectively. Furthermore, in the present study, patients' 2-year overall survival rates were slightly higher than in the study of Hsieh et al.

Korpics et al. compared RT vs. CRT in elderly bladder cancer patients. In this study, the researchers used the National Cancer Data Base. The data of 1369 bladder cancer patients who were clinically $\mathrm{T} 2-4, \mathrm{~N} 0-3, \mathrm{M} 0$ were examined. The median age of the patients was 84 (range 80 90). Seventy-nine (54\%) of the patients received RT without chemotherapy and $630 \quad(46 \%)$ received CRT. The RT dose used was 60-70 Gy. The 2-year overall survival of all patients was $48 \%$. The two-year overall survival of patients receiving RT without chemotherapy and patients receiving CRT was $42 \%$ and $56 \%$, respectively (P $<.0001)$. The authors concluded that the addition of chemotherapy to RT increases survival in 
elderly patients ${ }^{27}$. However, in our present study, the addition of chemotherapy to radiotherapy did not cause a difference in survival.

In our study, the 2-year overall survival was $37 \%$ and the median survival was 18 months. These results are lower than in most, but not all, other studies in older patients with bladder cancer ${ }^{26,27}$. When the general characteristics of the patients included in the study were examined, it was observed that it was a very fragile group. Due to the high rate of comorbidity, the majority of patients being at high risk for bladder-sparing treatment, and almost half of the patients failing to receive concomitant chemotherapy, patients could not complete their treatment optimally. The reasons listed above may explain why our patients' survival rates are low. However, in our study, when the side effects of treatments were examined, we obtained similar results to other studies. In the acute phase, grade 3-4 toxicity was around $2 \%$ for the genitourinary and $6-8 \%$ for the hematologic toxicities. In the late period, only one patient had gastrointestinal side effects with biopsy proven. There may be a need to step out of routine practice when making treatment decisions of elderly patients. In most cases, the lack of optimal treatment may adversely affect treatment outcomes in this patient group.

The limitations of this study are the retrospective nature of the study, the small number of patients, and the fact that most patients were not good candidates for bladder-sparing treatment.

\section{REFERENCES}

1. Efstathiou JA and Zietman AL. Bladder Cancer (chapter 54). Gunderson LL and Tepper JE (ed.). Clinical Radiation Oncology (4th Edittion). Elsevier 2016: pp:1096-1120.

2. Haskell cancer treatment. 5th ed. Ch. 51. 2001. P:828-45.

3. Ro JY, Staerkel GA, Ayala AG. Cytologic and histologic features of superficial bladder cancer. Urol Clin North Am 1992;19:435-53.

4. Saad A, Hanbury DC, McNicholas TA, Boustead GB, Morgan S, Woodman AC. A study comparing various noninvasive methods of detecting bladder cancer in urine. BJU International 2002;89:369-73.

5. Soloway MS, Sofer M, Vaidya A. Contemporary management of stage $\mathrm{T} 1$ transitional cell carcinoma of the bladder. J Urol 2002;167:1573-83.

6. Gakis G, Efstathiou J, Lerner SP, et al. ICUD-EAU International Consultation on
Bladder Cancer 2012: radical cystectomy and bladder preservation for muscleinvasive urothelial carcinoma of the bladder. European Urology 2013;63(1):45-57.

7. Biagioli MC, Fernandez DC, Spiess PE, Wilder RB. Primary bladder preservation treatment for urothelial bladder cancer. Cancer Control 2013;20(3):188-99.

8. Cahn DB, Ristau BT, Ghiraldi EM, et al. Bladder preservation therapy: a review of the literature and future directions. Urology 2016;96:54-61.

9. Schultzel M, Saltzstein SL, Downs TM, et al. Late age (85 years or older) peak incidence of bladder cancer. $J$ Urol (2008);179(4):1302-6.

10. Amin MB, Edge SB, Greene FL, et al. AJCC Cancer Staging Manual. Ed. 8 Cham, Switzerland: Springer; 2017.

11. Moch H, Humphrey PA, Ulbright TM, Reuter VE. WHO Classification of Tumours of the Urinary System and Male Genital Organs. Geneva, Switzerland: WHO Press; 2016

12. Oken MM, Creech RH, Tormey DC, et al. Toxicity And Response Criteria Of The Eastern Cooperative Oncology Group. Am J Clin Oncol 1982;5:649-55.

13. Cox JD, Stetz J, Pajak TF. Toxicity criteria of the Radiation Therapy Oncology Group (RTOG) and the European Organization for Research and Treatment of Cancer (EORTC). Int $\mathrm{J}$ Radiat Oncol Biol Phys 1995;31:1341-6.

14. Charlson ME, Pompei P, Ales KL, MacKenzie CR. A new method of classifying prognostic comorbidity in longitudinal studies: devel"opment and validation. Journal of Chronic Diseases 1987;40:373-83.

15. Tester W, Porter A, Asbell S, et al. Combined modality program with possible organ preservation for invasive bladder carcinoma: results of RTOG protocol 85-12. International Journal of Radiation Oncology Biology Physics 1993;25(5):783-90.

16. Hagan MP, Witner KA, Kaufman DS, et al. RTOG 97-06: initial report of a phase I-II trial of selective bladder conservation using TURBT, twice-daily accelerated irradiation sensitized with cisplatin, and adjuvant MCV combination chemotherapy. International Journal of Radiation Oncology Biology Physics, 2003;57(3):665-72. 
17. von der Maase H, Hansen SW, Roberts JT, et al. Gemcitabine and cisplatin versus methotrexate, vinblastine, doxorubicin, and cisplatin in advanced or metastatic bladder cancer: results of a large, randomized, multinational, multicenter, phase III study. Journal of Clinical Oncology 2000;18(17):3068-77.

18. Tester W, Porter A, Asbell S, et al. Combined modality program with possible organ preservation for invasive bladder carcinoma: results of RTOG protocol 85-12. International Journal of Radiation Oncology Biology Physics 1993;25(5):783-90.

19. Shipley WU, Witner KA, Kaufman DS, et al. Phase III trial of neoadjuvant chemotherapy in patients with invasive bladder cancer treated with selective bladder preservation by combined radiation therapy and chemotherapy: initial results of Radiation Therapy Oncology Group 89-03. Journal of Clinical Oncology 1998;16(11):3576-83.

20. Kaufman DS, Winter KA, Shipley WU, et al. The initial results in muscle-invading bladder cancer of RTOG 95-06: phase I/II trial of transurethral surgery plus radiation therapy with concurrent cisplatin and 5fluorouracil followed by selective bladder preservation or cystectomy depending on the initial response. The Oncologist 2000;5(6):471-6.

21. Kaufman DS, Winter KA, Shipley WU, et al. Phase I-II RTOG study (99-06) of patients with muscle-invasive bladder cancer undergoing transurethral surgery, paclitaxel, cisplatin, and twice-daily radiotherapy followed by selective bladder preservation or radical cystectomy and adjuvant chemotherapy. Urology 2009;73(4):833-7.

22. Giacalone NJ, Shipley WU, Rebecca HC, et al. Long-term outcomes after bladderpreserving tri-modality therapy for patients with muscle-invasive bladder cancer: an updated analysis of the Massachusetts General Hospital experience. European Urology 2017;71(6):952-60.

23. Wujanto C, Tey J, Chia D, et al. Radical radiotherapy in older patients with muscle invasive bladder cancer. Journal of Geriatric Oncology 2019;10(2):292-7.

24. Lee $\mathrm{YT}, \mathrm{Wu} \mathrm{YT}$, Yen $\mathrm{CC}$, et al. Concurrent chemoradiotherapy in elderly patients with muscle-invasive bladder cancer: A single-center experience. Journal of Cancer Research and Practice 2016;3(3):73-6.

25. Turgeon GA, Souhami L, Cury FL, et al. Hypofractionated intensity modulated radiation therapy in combined modality treatment for bladder preservation in elderly patients with invasive bladder cancer. International Journal of Radiation Oncology Biology Physics 2014;88(2):326-31.

26. Hsieh $\mathrm{CH}$, Chung SD, Chan $\mathrm{PH}$, et al. (2011). Intensity modulated radiotherapy for elderly bladder cancer patients. Radiation Oncology 2011;6(1):75.

27. Korpics MC, Block AM, Martin B, et al. (2017). Concurrent chemotherapy is associated with improved survival in elderly patients with bladder cancer undergoing radiotherapy. Cancer 2017;123(18):3524-31. 